\title{
Moisture content at harvest and drying temperature on bean seed quality ${ }^{1}$
}

\author{
Maurício Albertoni Scariot ${ }^{2}$, Guilherme Tiburski ${ }^{3}$, \\ Francisco Wilson Reichert Júnior ${ }^{4}$, Lauri Lourenço Radünz ${ }^{2}$, Michele Renata Revers Meneguzzo ${ }^{5}$
}

\section{ABSTRACT}

The physical quality and physiological performance of seeds may be influenced by numerous factors, including the moisture content at harvest and drying temperature. This study aimed at evaluating the physical quality and physiological performance of black bean seeds (BRS Campeiro cultivar), depending on the moisture content at harvest and drying air temperature. The experiment was conducted under a completely randomized design, in a 3 x 5 (moisture content at harvest $\mathrm{x}$ drying air temperature) factorial arrangement, with four replications. The samples were collected when the seeds reached the moisture contents of $35.2 \%, 25.2 \%$ and $16.6 \%$. After harvesting, the seeds were subjected to drying at temperatures of $30{ }^{\circ} \mathrm{C}, 35^{\circ} \mathrm{C}, 40{ }^{\circ} \mathrm{C}, 45^{\circ} \mathrm{C}$ and $50{ }^{\circ} \mathrm{C}$. The physical quality of the seeds was evaluated by determining the 1,000-seed weight and hectoliter weight. The physiological performance was evaluated by the germination speed index, germination first count, accelerated aging, dry matter, seedling shoot and root length and electrical conductivity. The increase in the drying temperature, regardless of the moisture content at harvest, reduces the physical quality and physiological performance of the seeds. When subjected to drying temperatures lower than $40{ }^{\circ} \mathrm{C}$, the seeds obtained from the earliest harvests show a better physical quality and physiological performance.

KEYWORDS: Phaseolus vulgaris L.; harvest anticipation; thermal damage; germination.

\section{INTRODUCTION}

Bean (Phaseolus vulgaris L.) is considered one of the most important foods of the Brazilian diet. Moreover, it is a major source of income for farmers with low technological support (Silva \& Wander 2013). The total production of the bean crop in the 2016/2017 growing season was 3,274

\section{RESUMO}

Teor de água na colheita e temperatura de secagem sobre a qualidade de sementes de feijão

A qualidade física e o desempenho fisiológico de sementes podem ser influenciados por inúmeros fatores, dentre eles o teor de água na colheita e a temperatura de secagem. Objetivou-se avaliar a qualidade física e o desempenho fisiológico de sementes de feijão preto (cultivar BRS Campeiro), em função do teor de água na colheita e da temperatura do ar de secagem. O experimento foi realizado sob delineamento inteiramente casualizado, em esquema fatorial $3 \times 5$ (teor de água na colheita $\mathrm{x}$ temperatura do ar de secagem), com quatro repetições. As colheitas foram realizadas quando as sementes atingiram os teores de água de 35,2 \%; 25,2 \%; e 16,6 \%. Após a colheita, as sementes foram submetidas a secagem nas temperaturas de $30^{\circ} \mathrm{C}, 35^{\circ} \mathrm{C}, 40^{\circ} \mathrm{C}, 45^{\circ} \mathrm{Ce} 50^{\circ} \mathrm{C}$. A qualidade física das sementes foi avaliada por meio da determinação do peso de mil sementes e do peso hectolitro. Já o desempenho fisiológico foi avaliado pelo índice de velocidade de germinação, primeira contagem de germinação, envelhecimento acelerado, matéria seca, comprimento da parte aérea e raiz das plântulas e condutividade elétrica. A elevação da temperatura de secagem, independentemente do teor de água na colheita, reduz a qualidade física e o desempenho fisiológico das sementes. Quando submetidas a temperaturas de secagem inferiores a $40^{\circ} \mathrm{C}$, as sementes obtidas das colheitas realizadas antecipadamente apresentam melhor qualidade física e desempenho fisiológico.

PALAVRAS-CHAVE: Phaseolus vulgaris L.; antecipação de colheita; danos térmicos; germinação.

million tons, from an area of 3,028.3 hectares, which results in an average yield of $1,081 \mathrm{~kg} \mathrm{ha}^{-1}$ (Conab 2017).

The use of high quality seeds is one of the determining factors for high yield in a bean crop, as it provides a better plant stand and establishment in the field (Binotti et al. 2008). Seed quality is made up of a series of physical, genetic, sanitary and physiological

1. Manuscript received in Sep./2016 and accepted for publication in Mar./2017 (http://dx.doi.org/10.1590/1983-40632016v4743135).

2. Universidade Federal do Rio Grande do Sul, Faculdade de Agronomia, Departamento de Fitossanidade, Porto Alegre, RS, Brazil. E-mails: mauricioalbertoniscariot@gmail.com, laurilr@gmail.com.

3. Universidade Federal da Fronteira Sul, Erechim, RS, Brazil.E-mail: guilhermetiburski_gui@hotmail.com.

4. Universidade Federal de Santa Catarina, Florianópolis, SC, Brazil. E-mail: chicowrj@gmail.com.

5. Universidade Federal de Pelotas, Pelotas, RS, Brazil.E-mail: michelemeneguzzo@yahoo.com.br. 
factors. However, it is at their physiological maturity that the seeds reach the maximum quality potential, which tends to reduce over time (Rodo et al. 2000). Therefore, the seeds should be harvested as soon as they reach the physiological maturity.

The delay in harvesting makes seeds more susceptible to damages caused by environmental conditions. Thus, the anticipation of harvest aims to collect seeds at the physiological maturity point. However, with this anticipation, seeds may have a high moisture content, which may cause deterioration during storage. Methods such as artificial drying contribute to the rapid reduction of the moisture content of seeds, providing quality maintenance and thus enabling storage. However, the drying process can trigger chemical, physical and biological reactions, causing damage to the physical quality and physiological performance of seeds (Garcia et al. 2005).

Temperature is one of the most important factors during the drying process, as it can compromise the quality of seeds and become lethal, if applied at high levels. High drying rates promote cracking, increase the permeability of the integument, reduce the germination and germination speed, and may result in dead seeds or abnormal seedlings (Peske \& Villela 2003). In addition, seeds with high initial moisture content may suffer more severe damage when subjected to drying at high temperatures, when compared to seeds with lower moisture content. Therefore, different drying air temperatures should be used to dry seeds with different initial moisture content (Popinigis 1985).

Some studies have addressed the effects of drying temperature on the physical and physiological quality of oat seeds, adzuki bean and sorghum (Oliveira et al. 2010, Ullmann et al. 2015). In relation to beans, Afonso Júnior \& Corrêa (2000) and Faroni et al. (2006) studied the effects of different drying temperatures on the physical and physiological quality of seeds and bean grains, respectively, harvested with different moisture contents. However, there are no current references on the effects of drying temperature on the physical and physiological quality of black bean seeds harvested at different moisture contents.

Therefore, this study aimed at evaluating the physical quality and physiological performance of black bean seeds, due to different moisture levels at harvest and different drying air temperatures.

\section{MATERIAL AND METHODS}

The black bean seeds (BRS Campeiro cultivar) used in the experiment were obtained from the experimental area of the Universidade Federal da Fronteira Sul, in Erechim, Rio Grande do Sul State, Brazil, in the 2016 season. The cultivation was carried out under a no-tillage system, with fertilization, and the control of weeds, insects and diseases was performed according to technical recommendations for the bean crop (CTSBF 2012).

The experiment was also conducted at the Universidade Federal da Fronteira Sul, in a completely randomized design, arranged in a $3 \times 5$ factorial scheme (moisture content at harvest $\mathrm{x}$ drying air temperature), with four replications.

Harvesting and threshing were performed manually by plucking the pods, when the seeds reached the moisture contents of $35.2 \%, 25.2 \%$ and $16.6 \%$. The monitoring of the seeds moisture content in the field was carried out with the aid of a moisture portable meter (Motomco 999-RF model) and confirmed by the oven method at $105 \pm 3{ }^{\circ} \mathrm{C}$, for 24 h (Brasil 2009).

After each harvest, samples containing $500 \mathrm{~g}$ of seeds were placed in paper bags and then taken to a drying oven with forced air circulation (stationary drying) at $30{ }^{\circ} \mathrm{C}, 35{ }^{\circ} \mathrm{C}, 40{ }^{\circ} \mathrm{C}, 45{ }^{\circ} \mathrm{C}$ and $50{ }^{\circ} \mathrm{C}$. The drying was performed until the seeds reached approximately $11 \%$ of moisture content. The moisture content was determined by the oven method at $105 \pm 3{ }^{\circ} \mathrm{C}$, for $24 \mathrm{~h}$ (Brasil 2009). Each treatment consisted of four samples of $500 \mathrm{~g}$ of seeds, which configured the replicates. The physical quality and physiological performance of the seeds were assessed immediately after drying.

The 1,000-seed weight was determined by the average weight of eight replicates of 100 seeds per treatment, with results expressed in grams. The hectoliter weight was determined with the aid of a hectoliter scale with $250 \mathrm{~mL}$ capacity. The values were obtained by the average of three replicates and the results expressed in $\mathrm{kg} \mathrm{hL}^{-1}$ (Brasil 2009).

The electric conductivity was performed using four samples of 50 seeds per treatment. The samples were weighed, placed in containers and immersed in $75 \mathrm{~mL}$ of distilled water. The containers were kept in BOD chambers at $25 \pm 3{ }^{\circ} \mathrm{C}$. Evaluations were performed at $24 \mathrm{~h}$ after soaking the seeds, with the aid of a bench conductivity meter (Gehaka CG1800 
model). The results were expressed in $\mu \mathrm{S} \mathrm{cm}^{-1} \mathrm{~g}^{-1}$ (Marcos-Filho et al. 1987).

The germination test was conducted in Germitest paper rolls, soaked in distilled water at a ratio of 2.5 times its weight and maintained in a germination chamber at $25 \pm 3{ }^{\circ} \mathrm{C}$ and photoperiod of $12 \mathrm{~h}$. A total of 400 seeds per treatment were used, distributed in eight repetitions of 50 seeds. The evaluations were conducted according to Brasil (2009) and the results expressed as percentage of normal seedlings, on the 9th day after sowing. The first count was conducted jointly with the germination test. Assessments occurred at 5 days after sowing, by counting the number of normal seedlings, and the results were expressed in percentage of germination (Brasil 2009).

The germination speed index was conducted simultaneously to the germination test, by counting the number of normal germinated seeds per day, from sowing to the 5 th day, being determined as proposed by Maguire (1962) and calculated by the following equation:

$$
\mathrm{GSI}=\frac{\mathrm{G} 1}{\mathrm{~N} 1}+\frac{\mathrm{G} 2}{\mathrm{~N} 2}+\frac{\mathrm{Gn}}{\mathrm{Nn}}
$$

where GSI is the germination speed index; G1, G2, ..., Gn the number of normal seedlings in the first, second and final count; and N1, N2, ..., Nn the number of days from sowing to first, second and last count.

For the accelerated aging test, the seeds were placed in germination boxes containing $50 \mathrm{~mL}$ of distilled water, suspended with an iron net and placed in a growth chamber at a temperature of $41{ }^{\circ} \mathrm{C}$, for $72 \mathrm{~h}$ (Marcos-Filho et al. 1987). After that, the test was conducted as described for the germination test. The number of normal seedlings was evaluated at the 5th day after sowing and the results expressed as percentage.

The root and shoot length were jointly determined with the germination test, by measuring, with the aid of a millimeter graduated ruler, the shoot and root of 10 seedlings collected randomly on each roll. The lengths were expressed in $\mathrm{cm}$ seedling ${ }^{-1}$.

The dry matter transfer test was performed jointly with the germination test. The two cotyledons of the normal seedlings were cut and dried at the temperature of $80{ }^{\circ} \mathrm{C}$, for $24 \mathrm{~h}$. The results were expressed in $\mathrm{g}^{\circ}$ seedling ${ }^{-1}$ (Menezes \& Silveira 1995).
For the analyzes of first count, germination speed index, accelerated aging and dry seedling length and weight, only germinated seedlings with at least $2 \mathrm{~cm}$ of shoot and root protrusion were considered as normal.

The data were submitted to analysis of variance by the F test $(\mathrm{p} \leq 0.05)$, using the Statistica software 10.0. The variables analyzed were submitted to regression analysis and Pearson correlation $(\mathrm{p} \leq 0.05)$, through the Sigma Plot ${ }^{\circledR} 10.0$ and Statistica 10.0 softwares, respectively.

\section{RESULTS AND DISCUSSION}

According to the F test $(\mathrm{p} \leq 0.05)$, there was a significant interaction between the harvest moisture content and the drying air temperature factors for all variables analyzed, except for root length, which showed only the main effect for the harvest moisture content.

Regardless of the moisture content at harvest, the increase of the drying air temperature had a negative influence on the physical and physiological quality of the black bean seeds. Furthermore, seeds with higher moisture content suffered a more pronounced damage when combined with high drying temperatures (Figures 1 and 2).

The regressions obtained for the 1,000-seed weight and hectoliter weight are shown in Figure 1.

There was a linear decrease in the 1,000-seed weight and an exponential one for the hectoliter weight of the seeds with increasing drying air temperature, regardless of the moisture content at harvest. These results agree with those obtained by Eichelberger \& Portella (2003) and Oliveira et al. (2010), which studied the drying of corn and oat grains. They found that increasing the drying temperature resulted in the reduction of the 1,000-seed weight and hectoliter weight of the grains.

The reduction in the 1,000-seed weight and hectoliter weight of seeds may be related to thermal damages such as cracks and fissures, which cause a volume expansion of the seed and the appearance of empty spaces. These spaces voids can accelerate dehydration and possibly the leakage of cellular content, reducing the seed weight (Eichelberger \& Portella 2003, Menezes et al. 2012).

The seeds harvested with $35.2 \%$ of moisture content were more susceptible to damage caused by the increase in drying air temperature. This is 


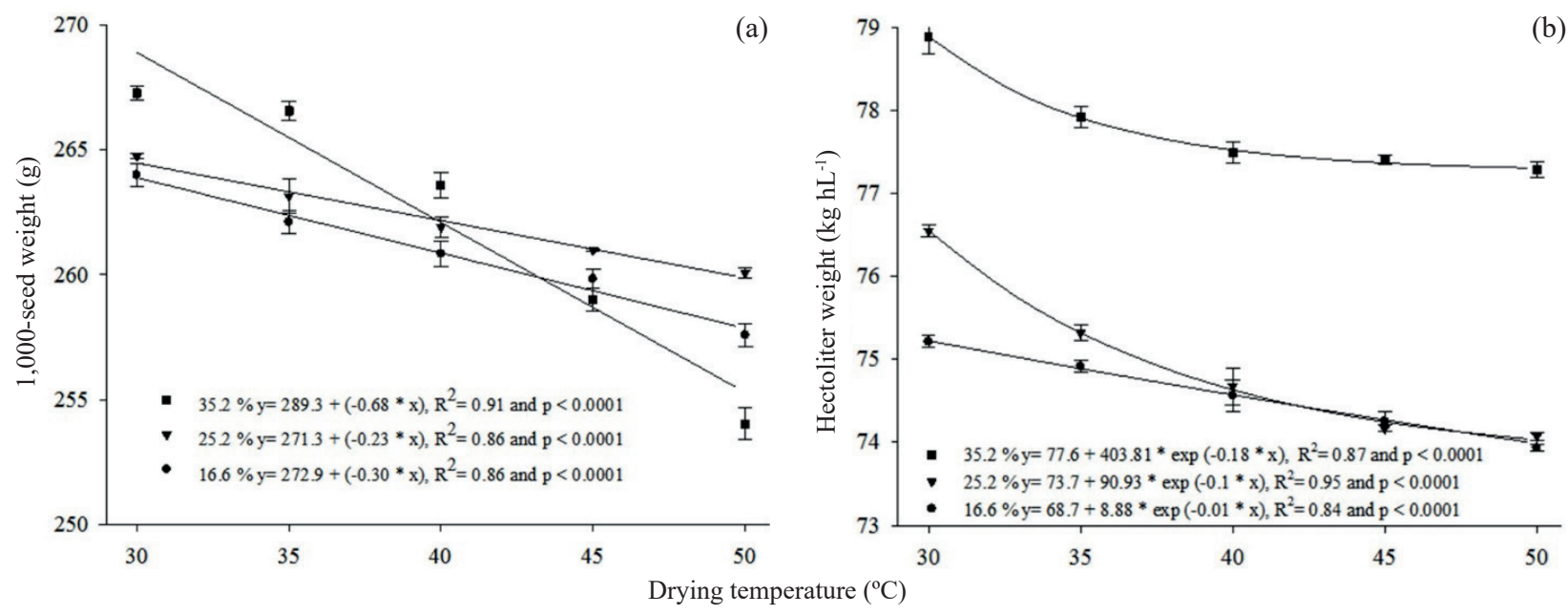

Figure 1. 1,000-seed weight (a) and hectoliter weight (b) of black bean seeds (BRS Campeiro cultivar) harvested with different moisture contents and submitted to different drying temperatures.

because seeds with a high initial moisture content, when subjected to high drying temperatures, show an increase in the vapor pressure gradient between the interior of the seed and the drying air, resulting in high rates of drying and hence the highest probability of occurrence of cracks and fissures (Eichelberger \& Portella 2003).

The delay in harvesting caused a reduction in the 1,000-seed weight and hectoliter weight. Seeds harvested with $35.2 \%$ of moisture content, when subjected to drying air temperatures below $40{ }^{\circ} \mathrm{C}$, had higher 1,000-seed weight and, regardless of the drying air temperature, reached a higher hectoliter weight, if compared to the other harvests. These results agree with Tunes et al. (2008), who found that the delay in the harvest of barley seeds caused a reduction in the 1,000-seed weight and hectoliter weight. The delay in harvesting seeds makes them susceptible to relative moisture and air temperature changes, accelerating the process of respiration and degradation of reserves, reflecting in lower values of 1,000-seed weight and hectoliter weight (Peske \& Barros 2006).

According to the regressions obtained for germination, first count, germination speed index, dry matter, accelerated aging and shoot length, there was a reduction of the physiological performance of the seeds with higher drying temperature, regardless of the moisture content at harvest (Figure 2).

Germination decreased with the higher drying air temperature, except for the harvest with $16.6 \%$ of moisture content, which showed no significant statistical difference in the drying air temperatures, with an average of $96.6 \%$. A similar result was obtained by Ahrens et al. (2000), who found no negative effect of the temperature rise of the drying air up to $67^{\circ} \mathrm{C}$, on germination of white oat seeds harvested with $21 \%$ of moisture content.

However, the seeds harvested with $35.2 \%$ and $25.2 \%$ of moisture content showed a linear decrease in germination, with the increase in the drying air temperature. These results conform to those by Afonso Júnior \& Corrêa (2000), who found a reduction in the bean seeds germination when harvested with $25.5 \%$ and $37.3 \%$ of moisture content, with the increase of drying air temperature to $50{ }^{\circ} \mathrm{C}$. Similar results were also observed by Almeida et al. (2013), studying the drying of adzuki bean (Vigna angularis) harvested with $53 \%$ of moisture content and subjected to drying air temperatures up to $75^{\circ} \mathrm{C}$.

The loss of seed germination potential is among the thermal damages caused by high drying temperatures. Seeds with higher moisture content have greater susceptibility to damages during the drying process than dry seeds. Quick dewatering inside the seed may result in damage to cell structures (Corrêa \& Afonso Júnior 1999, Garcia et al. 2004). The germination test provides favorable conditions of temperature and humidity for the development of seeds and may, thus, overestimate the maximum germination capacity (Marcos-Filho 2005). Therefore, the results obtained for the harvest with $16.6 \%$ of moisture content may be due to the insensitivity of the germination test to observe the 


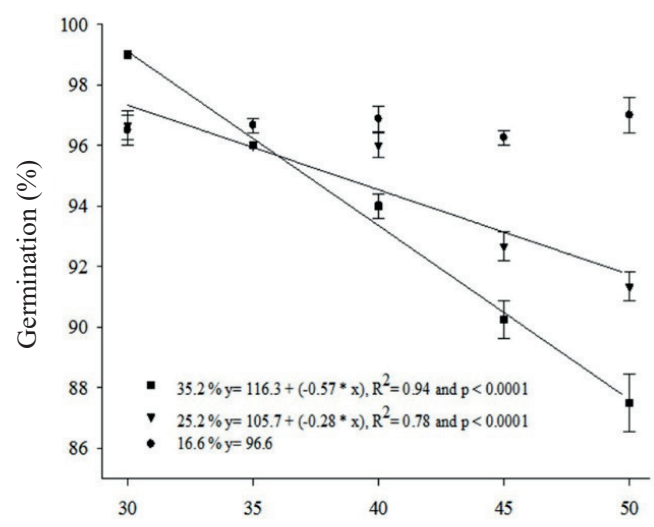

(a) damage caused by the increase in the drying air temperature.

The vigor of bean seeds was negatively affected by increases in the drying air temperature. There was a linear reduction of the variables, regardless of the moisture content at harvest.

Higher drying air temperatures caused a reduction in the seed first count values for all harvest moisture contents. Similar results were obtained by Alfonso Júnior \& Corrêa (2000), who reported a

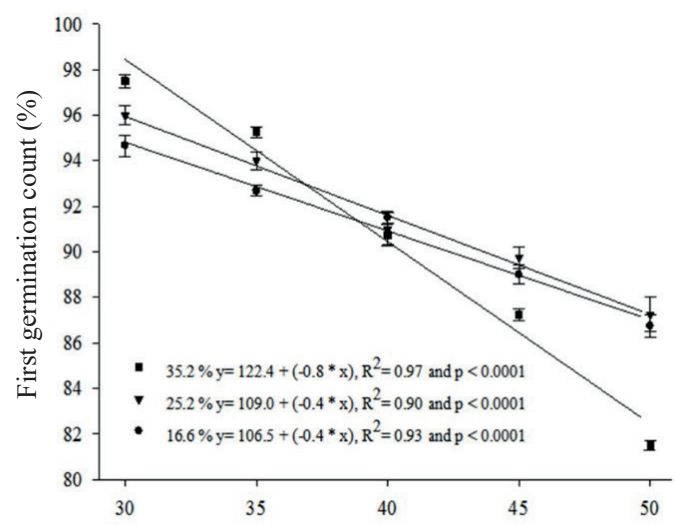

(b)
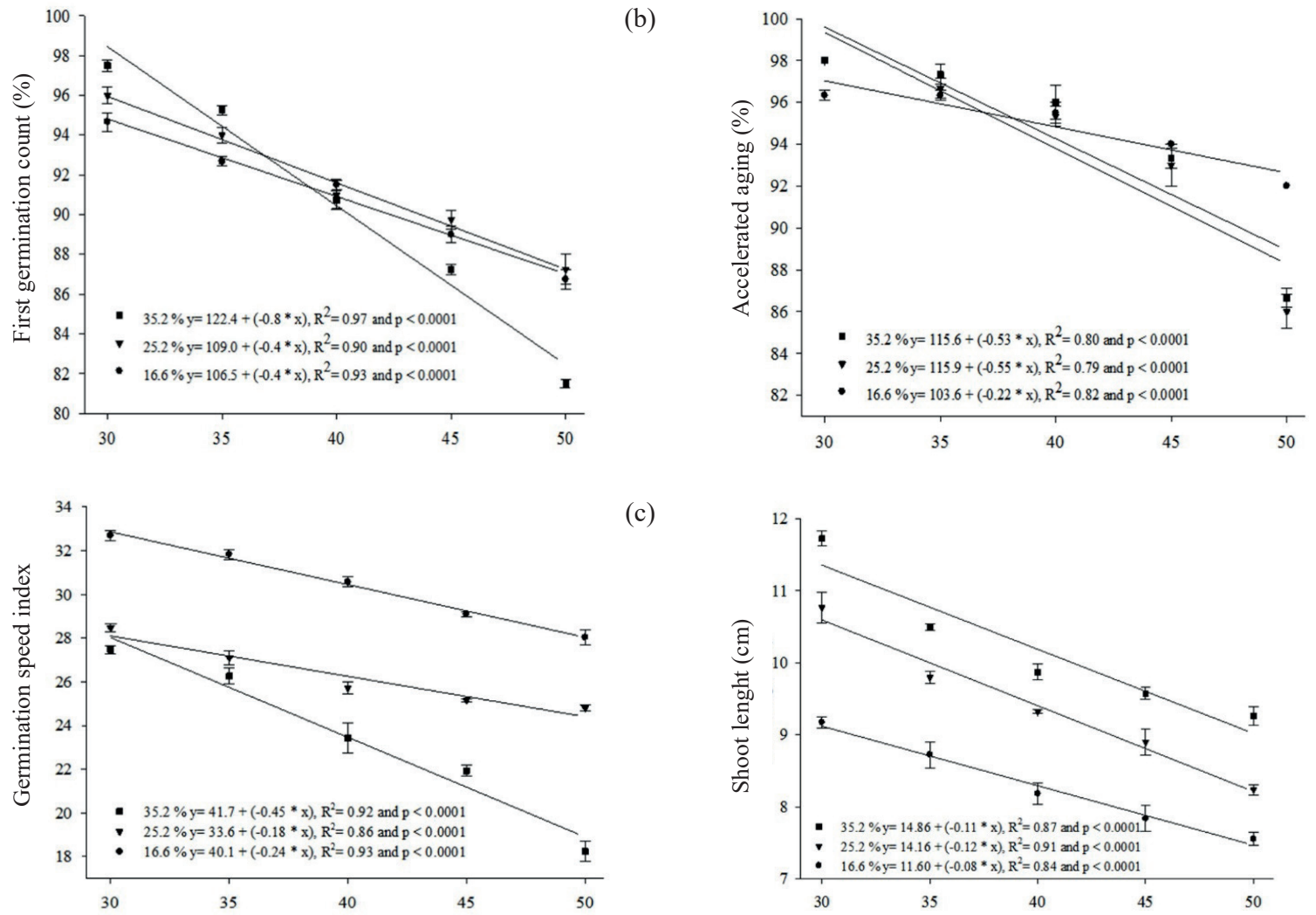

(c)
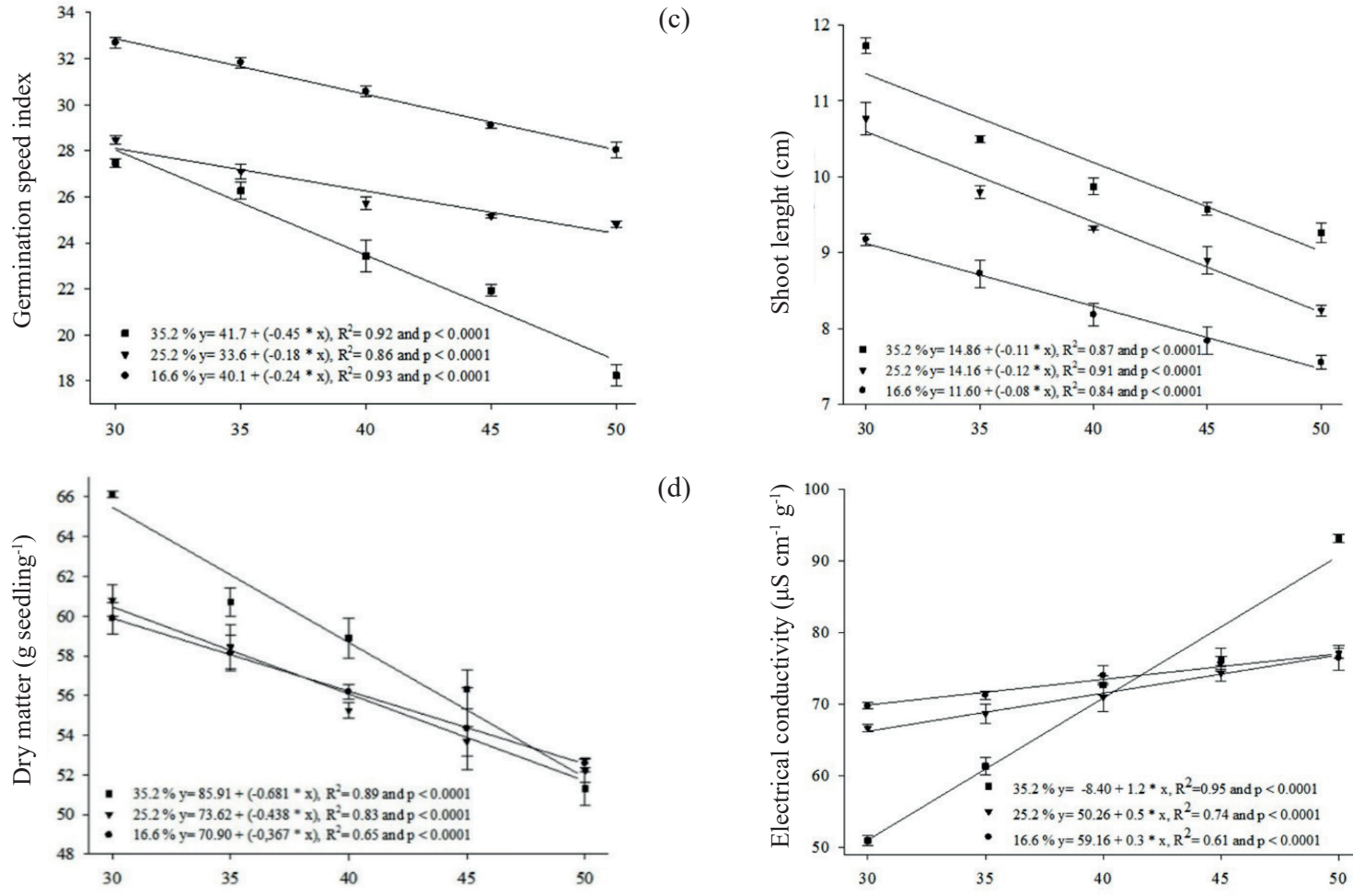

(d)

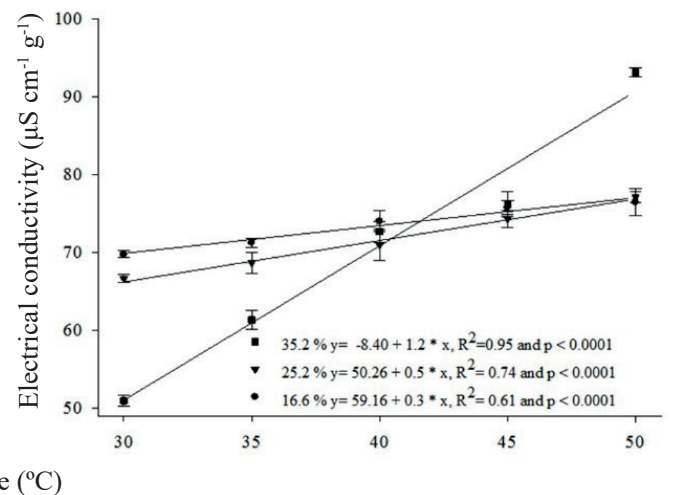

(g)

Figure 2. Germination (a), first germination count (b), germination speed index (c), dry matter (d), accelerated aging (e), shoot length (f) and electrical conductivity (g) of black bean seeds (BRS Campeiro cultivar) harvested with different moisture contents and submitted to different drying temperatures. 
reduction of first count of bean seeds, independently of moisture content at harvest, with increases in the drying air temperature. Also, Menezes et al. (2012) reported a negative effect of increasing the drying temperature to $50{ }^{\circ} \mathrm{C}$ on the first count of rice seed germination, when harvested with a moisture content of approximately $24 \%$.

Moreover, when subjected to lower drying air temperatures $\left(30^{\circ} \mathrm{C}\right.$ and $\left.35^{\circ} \mathrm{C}\right)$, seeds harvested with a higher moisture content showed a higher first count. This fact can be attributed to the deterioration of the seeds in the field, due to the delay in harvesting. A similar result was obtained by Tunes et al. (2008), in barley seeds, who observed a negative effect of delayed harvest on the first count.

The speed germination index decreased with higher drying air temperatures, regardless of the moisture content at harvest. These results agree with those obtained by Almeida et al. (2013), studying the drying of adzuki bean (Vigna angularis), harvested with $53 \%$ of moisture content and subjected to temperatures exceeding $55{ }^{\circ} \mathrm{C}$. A reduction in the germination speed of sorghum seeds, harvested with a moisture content of approximately $23 \%$ and dried at temperatures up to $100{ }^{\circ} \mathrm{C}$, was also observed by Ullmann et al. (2015).

However, the early harvest reduced the germination speed, regardless of the drying temperature. This result may be due to the action of hormones, such as abscisic acid. According to Rock \& Quatrano (1995), the concentration of abscisic acid is greater during the initial stages of seed development and decreases with the progress of the embryo maturation. Thus, seeds harvested with higher moisture contents may also have a higher abscisic acid hormone inhibiting germination.

Seedling dry matter decreased with higher drying air temperatures, regardless of the harvest time. When subjected to drying air temperatures below $40{ }^{\circ} \mathrm{C}$, the seeds harvested with $35.2 \%$ of moisture content had higher values for seedlings dry matter, showing the negative effect of the delayed harvest on this variable. According to Dan et al. (1987), in legumes, the amount of reserves and the ability of the cotyledons to nurture the embryo during germination are indicators of seed vigor.

The shoot length was negatively influenced by the increases in the drying air temperature. The delay in harvesting also decreased the shoot length, regardless of the drying air temperature. Similar results were obtained for the length of rice seedlings, which reduced with higher drying air temperatures (Menezes et al. 2012).

Root length was not affected by increasing drying air temperatures. However, the delay in harvesting caused a reduction on seedlings root length. The harvest of seeds with moisture content of $35.2 \%$ and $25.2 \%$ provided a greater root length, with averages of $11.85 \mathrm{~cm}$ and $11.86 \mathrm{~cm}$, respectively. On the other hand, the harvest of seeds with $16.6 \%$ of moisture content generated seedlings with significantly shorter roots $(11.25 \mathrm{~cm})$.

Length measurements of seedlings or their parts are an indicator of seed vigor, as more vigorous seeds have a greater capacity to nourish the embryo, resulting in a higher growth rate of seedlings (Dan et al. 1987).

Thus, the reduction of dry matter and shoot length of seedlings subjected to delayed harvest and increased drying air temperature may be related to deterioration in the field and thermal damage, respectively. These factors reduce the amount of available reserves, as observed for the 1,000-seed weight and hectoliter weight values.

The results obtained from the accelerated aging test showed that increasing the drying air temperature caused a reduction in seed vigor, regardless of the moisture content at harvest. However, seeds harvested with $25.2 \%$ and $35.2 \%$ of moisture content showed a greater reduction of vigor, when compared to seeds harvested with $16.6 \%$ of moisture content. Menezes et al. (2012) also observed, by using the accelerated aging test, that the increase in the drying air temperature caused a reduction of vigor in rice seeds. However, even with the decrease in germination values by the accelerated aging test, caused by an increase in the drying air temperature, the bean seeds, regardless of the moisture content at harvest, had high vigor, since the values obtained were close to those in the standard germination test. The germination values obtained were close to those in the standard germination test.

Regarding the electrical conductivity, there was a linear increase with higher drying air temperatures, regardless of the moisture content at harvest. On the other hand, when the seeds were dried at air temperatures below $40{ }^{\circ} \mathrm{C}$, the delay in harvesting resulted in seeds with higher values for electrical conductivity. However, increases in drying air temperature made seeds harvested with 
Table 1. Pearson correlation between the variables analyzed for black bean seeds (BRS Campeiro cultivar) harvested with different moisture contents and subjected to different drying temperatures.

\begin{tabular}{|c|c|c|c|c|c|c|c|c|c|}
\hline Variable & TSW & HW & $\mathrm{EC}$ & GP & $\mathrm{FC}$ & GSI & DM & SL & AA \\
\hline TSW & - & $0.85^{*}$ & $-0.88^{*}$ & $0.75^{*}$ & $0.91 *$ & $0.45^{*}$ & $0.82 *$ & $0.81 *$ & $0.88^{*}$ \\
\hline HW & - & - & $-0.35^{*}$ & -0.02 & $0.26^{*}$ & $-0.40^{*}$ & $0.81 *$ & $0.81 *$ & $0.30 *$ \\
\hline $\mathrm{EC}$ & - & - & - & $-0.81^{*}$ & $-0.88^{*}$ & $-0.62 *$ & $-0.81 *$ & $-0.65^{*}$ & $-0.82 *$ \\
\hline GP & - & - & - & - & $0.84^{*}$ & $0.75^{*}$ & $0.73 *$ & $0.26^{*}$ & $0,77^{*}$ \\
\hline $\mathrm{FC}$ & - & - & - & - & - & $0.63^{*}$ & $0.80^{*}$ & $0.62 *$ & $0.84 *$ \\
\hline GSI & - & - & - & - & - & - & $0.34^{*}$ & -0.16 & $0.53^{*}$ \\
\hline DM & - & - & - & - & - & - & - & $0.75^{*}$ & $0.72 *$ \\
\hline SL & - & - & - & - & - & - & - & - & $0.76^{*}$ \\
\hline $\mathrm{AA}$ & - & - & - & - & - & - & - & - & - \\
\hline
\end{tabular}

* Significant at $5 \%$, by the Pearson linear correlation analysis. TSW: 1,000-seed weight; HW: hectoliter weight; EC: electrical conductivity; GP: germination percentage; FC: first count; GSI: germination speed index; DM: dry matter of seedlings; SL: shoot length; AA: accelerated aging.

higher moisture content reach an increased electrical conductivity. These results are consistent with those found by Corrêa \& Afonso Júnior (1999), who also reported an increase in the electrical conductivity of bean seeds with higher drying air temperature. Furthermore, the authors found that seeds harvested with high moisture content are more susceptible to loss in quality during drying.

According to Andrade et al. (1999), for the same moisture content after drying, seeds harvested with higher moisture contents tend to reach a higher electrical conductivity, if compared to seeds harvested with lower moisture contents. This fact can be explained by the high rate of water removal inside the seed, which causes damage to the membrane structures and leakages of the cellular content.

The Pearson correlation matrix for the variables analyzed is shown in Table 1. The magnitude of the correlation coefficient can be classified as weak $(\mathrm{r} \leq 0.40)$, moderate $(0.40<\mathrm{r}<0.60)$ and strong $(r \geq 0.60)$ (Franzblau 1958).

The 1,000-seed weight showed a strong correlation with all the physiological variables analyzed, indicating that heavier seeds present higher physiological quality, corroborating the results by Pádua et al. (2010), for soybean seeds.

The hectoliter weight showed a high positive correlation with the variables shoot length and seedling dry matter. This result indicates that seeds with higher hectoliter weight present a greater capacity to nourish the embryo, resulting in larger seedlings, with greater accumulation of dry matter.

However, the correlations of the hectoliter weight with the electrical conductivity, germination, first germination count, germination speed index and accelerated aging presented low coefficients, indicating that the hectoliter weight did not have a substantial influence on these variables. This can be due to the reduction of the physiological performance of the seeds with the increase of the drying temperature, especially for the harvest with a moisture content of $35.2 \%$. Seeds with high water content are more susceptible to thermal damage during drying, due to the high rate of water withdrawal (Corrêa \& Afonso Júnior 1999). On the other hand, the harvest delay negatively influenced the hectoliter weight of the seeds, with the highest values for the harvest with a moisture content of $35.2 \%$, which may explain the unsatisfactory correlation coefficients found.

The analyzes of electrical conductivity, germination, first germination count, shoot length, seedling dry matter and accelerated aging presented high correlation coefficients among them, except for the correlation between germination and shoot length. In addition, the germination rate had low correlation with seedling dry matter and shoot length. These results may be attributed to the higher germination rate observed for seeds harvested in advance $(35.2 \%)$, due to the high concentration of germination inhibiting hormones present in seeds harvested near the point of physiological maturity (Rock \& Quatrano 1995). In contrast, seeds harvested in advance had higher values for seedling dry matter and shoot length, which may explain the poor correlation coefficients obtained.

\section{CONCLUSIONS}

1. The anticipation of harvest and drying seeds at temperatures below $40{ }^{\circ} \mathrm{C}$ result in common 
bean seeds with high physical and physiological performance;

2. Commom bean seeds (BRS Campeiro cultivar) harvested with higher moisture content are more susceptible to damage caused by high drying air temperature;

3. Heavier seeds have better physiological performance. However, the physiological performance of seeds may be reduced more sharply than the physical quality with higher drying temperatures.

\section{REFERENCES}

AFONSO JÚNIOR, P. C.; CORRÊA, P. C. Efeitos imediato e latente da secagem de sementes de feijão colhidas com diferentes níveis de umidade. Ciência e Agrotecnologia, v. 24, n. 1, p. 33-40, 2000.

AHRENS, D. C. et al. Secagem estacionária de sementes de aveia-branca (Avena sativa L.) empregando diferentes temperaturas do ar. Revista Brasileira de Sementes, v. 22, n. 2, p. 6-11, 2000.

ALMEIDA, D. P. et al. Influência da secagem na qualidade fisiológica do feijão adzuki. Revista Brasileira de Ciências Agrárias, v. 8, n. 2, p. 311-315, 2013.

ANDRADE, E. T. de et al. Avaliação de dano mecânico em sementes de feijão por meio de condutividade elétrica. Revista Brasileira de Engenharia Agrícola e Ambiental, v. 3, n. 1, p. 54-60, 1999.

BINOTTI, F. F. da S. et al. Efeito do período de envelhecimento acelerado no teste de condutividade elétrica e na qualidade fisiológica de sementes de feijão. Acta Scientiarum Agronomy, v. 30, n. 2, p. 247-254, 2008.

BRASIL. Ministério da Agricultura, Pecuária e Abastecimento. Regras para análise de sementes. Brasília, DF: MAPA/SDA/ACS, 2009.

COMISSÃO TÉCNICA SUL-BRASILEIRA DE FEIJÃO (CTSBF). Informações técnicas para o cultivo de feijão na Região Sul brasileira 2012. 2. ed. Florianópolis: Epagri, 2012.

COMPANHIA NACIONAL DE ABASTECIMENTO (Conab). Acompanhamento da safra brasileira: grãos: safra 2016/17: $6^{\circ}$ levantamento: março/2017. Brasília, DF: Conab, 2017.

CORRÊA, P. C.; AFONSO JÚNIOR, P. C. Uso do teste de condutividade elétrica na avaliação dos danos provocados por diferentes taxas de secagem em sementes de feijão. Revista Brasileira de Produtos Agroindustriais, v. 1, n. 1, p. 21-26, 1999.
DAN, E. L. et al. Transferência de matéria seca como método de avaliação do vigor de sementes de soja. Revista Brasileira de Sementes, v. 9, n. 3, p. 45-55, 1987.

EICHELBERGER, L.; PORTELLA, J. A. Secagem de grãos de milho em secador de leito fixo: danos físicos. Pesquisa Agropecuária Gaúcha, v. 9, n. 1-2, p. 85-91, 2003.

FARONI, L. R. A. et. al. Influência do conteúdo de umidade de colheita e temperatura de secagem na qualidade do feijão. Revista Brasileira de Engenharia Agrícola e Ambiental, v. 10, n. 1, p. 148-154, 2006.

FRANZBLAU, A. A primer of statistics for nonstatisticians. New York: Harcourt, Brace \& World, 1958.

GARCIA, D. C. et al. A secagem de sementes. Ciência Rural, v. 34, n. 2, p. 603-608, 2004.

GARCIA, D. C. et al. Qualidade fisiológica de sementes de trigo submetidas à secagem estacionária com ar ambiente forçado. Revista Brasileira de Sementes, v. 27, n. 1, p. 158166, 2005.

MAGUIRE, J. D. Velocidade de germinação na seleção e avaliação de emergência e vigor de plântulas. Crop Science, v. 2, n. 1, p. 176-177, 1962.

MARCOS-FILHO, J. Fisiologia de sementes de plantas cultivadas. Piracicaba: Fealq, 2005.

MARCOS-FILHO, J.; CÍCERO, S. M.; SILVA, W. R. Avaliação da qualidade de sementes. Piracicaba: Fealq, 1987.

MENEZES, N. L. de et al. Temperaturas de secagem na integridade física, qualidade fisiológica e composição química de sementes de arroz. Pesquisa Agropecuária Tropical, v. 42, n. 4, p. 430-436, 2012.

MENEZES, N. L. de; SILVEIRA, T. L. B. da. Métodos para avaliar a qualidade fisiológica de sementes de arroz. Scientia Agricola, v. 52, n. 2, p. 350-359, 1995.

OLIVEIRA, L. da C. et al. Efeito da temperatura de secagem na qualidade de grãos de aveia branca. Ciência e Agrotecnologia, v. 34, n. 2, p. 313-319, 2010.

PÁDUA, G. P. et al. Influência do tamanho da semente na qualidade fisiológica e na produtividade da cultura da soja. Revista Brasileira de Sementes, v. 32, n. 3, p. 9-16, 2010.

PESKE, S. T.; BARROS, A. C. S. A. Produção de sementes. In.: PESKE, S. T.; LUCCA FILHO, O. A.; BARROS, A. C. S. A. Sementes: fundamentos científicos e tecnológicos. 2. ed. Pelotas: Ed. UFPel, 2006. p. 15-98.

PESKE, S. T.; VILLELA, F. A. Secagem de sementes. In: PESKE, S. T.; ROSENTHAL, M. A.; ROTA, G. R. M. Sementes: fundamentos científicos e tecnológicos. Pelotas: Ed. UFPel, 2003. p. 366-413. 
POPINIGIS, F. Fisiologia da semente. Brasília, DF: Agiplan, 1985.

ROCK, C. D.; QUATRANO, R. S. The role of hormones during seed development. In: DAVIES, P. J. Plant hormones. Dordrecht: Kluwer Academic, 1995. p. 671697.

RODO, A. B.; PANOBIANCO, M.; MARCOS FILHO, J. Metodologia alternativa do teste de envelhecimento acelerado para sementes de cenoura. Scientia Agricola, v. 57, n. 2, p. 289-292, 2000.
SILVA, O. F. da; WANDER, A. E. O feijão comum no Brasil: passado, presente e futuro. Santo Antônio de Goiás: Embrapa Arroz e Feijão, 2013. (Documentos, 287).

TUNES, L. M. de et al. Testes de vigor em função de diferentes épocas de colheita de sementes de cevada (Hordeum vulgare L.). Revista Brasileira de Ciências Agrárias, v. 3, n. 4, p. 321-326, 2008.

ULLMANN, R. et al. Qualidade fisiológica das sementes de sorgo sacarino submetidas à secagem em diferentes condições de ar. Revista Brasileira de Engenharia Agrícola e Ambiental, v. 19, n. 1, p. 64-69, 2015. 